\title{
Ablation of Newly Generated Hippocampal Granule Cells Has Disease-Modifying Effects in Epilepsy
}

\author{
Dethany E. Hosford, ${ }^{1,4}$ John P. Liska, ${ }^{1}$ and ${ }^{-S}$ Steve C. Danzer ${ }^{1,2,3,4}$ \\ ${ }^{1}$ Department of Anesthesia, Cincinnati Children's Hospital Medical Center, Cincinnati, Ohio 45229, and ${ }^{2}$ Department of Anesthesia, ${ }^{3}$ Department of \\ Pediatrics, and ${ }^{4}$ Neuroscience Graduate Program, University of Cincinnati, Cincinnati, Ohio 45267
}

\begin{abstract}
Hippocampal granule cells generated in the weeks before and after an epileptogenic brain injury can integrate abnormally into the dentate gyrus, potentially mediating temporal lobe epileptogenesis. Previous studies have demonstrated that inhibiting granule cell production before an epileptogenic brain insult can mitigate epileptogenesis. Here, we extend upon these findings by ablating newly generated cells after the epileptogenic insult using a conditional, inducible diphtheria-toxin receptor expression strategy in mice. Diphtheria-toxin receptor expression was induced among granule cells born up to 5 weeks before pilocarpine-induced status epilepticus and these cells were then eliminated beginning $3 \mathrm{~d}$ after the epileptogenic injury. This treatment produced a $50 \%$ reduction in seizure frequency, but also a $20 \%$ increase in seizure duration, when the animals were examined 2 months later. These findings provide the first proof-of-concept data demonstrating that granule cell ablation therapy applied at a clinically relevant time point after injury can have disease-modifying effects in epilepsy.
\end{abstract}

Key words: cell ablation; dentate granule cell; diphtheria toxin receptor; epilepsy; neurogenesis; seizure duration

\section{Significance Statement}

These findings support the long-standing hypothesis that newly generated dentate granule cells are pro-epileptogenic and contribute to the occurrence of seizures. This work also provides the first evidence that ablation of newly generated granule cells can be an effective therapy when begun at a clinically relevant time point after an epileptogenic insult. The present study also demonstrates that granule cell ablation, while reducing seizure frequency, paradoxically increases seizure duration. This paradoxical effect may reflect a disruption of homeostatic mechanisms that normally act to reduce seizure duration, but only when seizures occur frequently.

\section{Introduction}

Hippocampal dentate granule cells are a unique population of neurons generated throughout life in mammals, including humans (Eriksson et al., 1998; Spalding et al., 2013). In the healthy brain, these new cells play important roles in memory and cognition (Aimone et al., 2014). After brain injuries that can lead to

Received April 25, 2016; revised Aug. 2, 2016; accepted Aug. 21, 2016.

Author contributions: B.E.H. and S.C.D. designed research; B.E.H. and J.P.L. performed research; S.C.D. contributed unpublished reagents/analytic tools; B.E.H., J.P.L., and S.C.D. analyzed data; B.E.H. and S.C.D. wrote the paper.

This work was supported by the National Institute of Neurological Disorders and Stroke-National Institutes of Health (Grants R01NS065020 and R01NS062806). The content is solely the responsibility of the authors and does not necessarily represent the official views of the National Institute of Neurological Disorders and Stroke or the National Institutes of Health. We thank Lili Ding (Cincinnati Children's Hospital Medical (enter, CCHMC) for assistance with statistical analyses, Keri Kaeding for assistance with earlier versions of this manuscript and the CCHMC Confocal Core for providing access the 3024 Nikon A1Rsi inverted microscope used in this study.

The authors declare no competing financial interests.

Correspondence should be addressed to Dr. Steve C. Danzer, Department of Anesthesia, Cincinnati Children's Hospital Medical Center, 3333 Burnet Avenue, ML 2001, Cincinnati, OH 45229-3039. E-mail: steve.danzer@cchmc.org.

DOI:10.1523/JNEUROSCI.1371-16.2016

Copyright $\odot 2016$ the authors $\quad 0270-6474 / 16 / 3611013-11 \$ 15.00 / 0$ the development of epilepsy, however, the integration of newly generated granule cells is disrupted. Cells generated after an epileptogenic brain injury can migrate to ectopic locations in the dentate hilus (Jessberger et al., 2007). Cells born 1 week before the insult can develop aberrant dendritic projections into the hilus (Walter et al., 2007), whereas cells born 1 month before the insult contribute to aberrant axonal sprouting in the dentate inner molecular layer (Kron et al., 2010). These morphological abnormalities create de novo recurrent excitatory loops within the dentate, a process hypothesized to promote temporal lobe epileptogenesis (Jessberger and Parent, 2015).

Consistent with this hypothesis, the addition of abnormal granule cells to an otherwise healthy brain leads to the development of epilepsy, demonstrating that abnormal granule cells are capable of causing the disease (Pun et al., 2012). Conversely, blocking neurogenesis has protective effects. In two separate studies conducted by Jung et al. $(2004,2006)$, treatment of animals with cell proliferation inhibitors at the time of an epileptogenic brain injury reduced the frequency of later spontaneous seizures. Similarly, recent work by Cho et al. (2015) demonstrates 
that ablating granule cell progenitors 4 weeks before an epileptogenic insult can reduce the frequency of epileptic seizures.

Ablating granule cell progenitors before an epileptogenic insult has limited clinical utility and has been shown in the kainic acid model of epilepsy to alter the severity of status epilepticus (Iyengar et al., 2015), confounding interpretation of postinjury results. Treatment with antineurogenic agents after the insult avoids this problem, but only targets a subset of the granule cell population hypothesized to promote epileptogenesis because cells born in the weeks before the insult also contribute to aberrant rewiring. To test robustly the role of newly generated cells in epilepsy, therefore, a strategy was needed that could be delayed until after the insult had occurred and would effectively ablate both newly generated cells and cells born before the insult.

To achieve this, we used a conditional, inducible transgenic cell ablation strategy that allows us to express the simian diphtheria toxin receptor (DTr) in newly generated granule cells beginning at any desired time point. In the present study, $\mathrm{DTr}$ expression was induced beginning 5 weeks before pilocarpineinduced epileptogenesis to target immature cells capable of forming recurrent circuits in these animals. Actual cell ablation was delayed until $3 \mathrm{~d}$ after pilocarpine treatment. This ensured that the insults were identical among groups and allowed us to test the therapy at a clinically relevant time point. Beginning 2 months later, animals were video-EEG monitored continuously to assess treatment efficacy.

\section{Materials and Methods}

Animals. All procedures complied with the National Institutes of Health's and institutional guidelines for the care and use of animals. NestinCreER ${ }^{\mathrm{T} 2}$ mice (Cicero et al., 2009), provided by Dr. Lionel Chow (Cincinnati Children's Hospital Medical Center, CCHMC), were maintained on a FVB/NJ background. Gt(ROSA)26Sor tm1(HBEGF)Awai/J mice (Jax Stock No: 007900; Buch et al., 2005) were maintained on a C57BL/6J background. These mice contain a loxP-flanked stop sequence in front of the simian DTr gene (heparin-binding EGF-like growth factor) and will be referred to as DTr mice for simplicity. GFP reporter mice (Nakamura et al., 2006), provided by Jeff Robbins (CCHMC), were maintained on a C57BL/6J background. Nestin$\mathrm{CreER}^{\mathrm{T} 2}$ mice were crossed with $\mathrm{DTr}^{+/-}:: \mathrm{GFP}^{+/-}$mice to generate the NestinCreER ${ }^{\mathrm{T} 2}$ hemizygous::: $\mathrm{Dr}^{+/-}:: \mathrm{GFP}^{+/-}$mice for the study. Animal crosses were designed to maintain a 50:50 ratio of FVB/NJ and C57BL/6 backgrounds for study mice. NestinCreER ${ }^{\mathrm{T} 2}$ hemizygous::DTr ${ }^{-1-}:$ : $\mathrm{GFP}^{+/-}$littermates were used as non-DTr-expressing controls. Mice were weaned at 3 weeks of age and same sex littermates were housed together (2-4 mice per cage) in a standard cage with normal chow and water ad libitum. Mice received weekly injections of tamoxifen (Sigma-Aldrich, T5648) starting at 3 weeks of age until 7 weeks of age ( 5 doses total, $250 \mathrm{mg} / \mathrm{kg} / \mathrm{dose}$ subcutaneous dissolved at $20 \mathrm{mg} / \mathrm{ml}$ in corn oil). A similar protocol labeled a robust population of abnormal granule cells (Hester and Danzer, 2013). Tamoxifen activates Cre-recombinase and induces the expression of DTr and GFP in nestin-expressing granule cell progenitors.

Pilocarpine and DT treatment. At 8 weeks of age (1 week after the last tamoxifen injection), mice were injected intraperitoneally with $1 \mathrm{mg} / \mathrm{kg}$ methyl scopolamine nitrate (Sigma-Aldrich, S2250) dissolved in sterile Ringer's solution. Mice were then placed in a standard cage that lacked bedding, food, and water to prevent accidental choking during status epilepticus. Fifteen minutes later, mice were injected intraperitoneally with $320 \mathrm{mg} / \mathrm{kg}$ pilocarpine (Sigma-Aldrich, P6503) dissolved in sterile Ringer's solution. After pilocarpine administration, mice were monitored continuously for signs of seizure activity. The onset of status epilepticus was defined by the occurrence of multiple class V (tonic/clonic) seizures (Racine, 1972), followed by persistent seizure activity (usually class II/III). Three hours after the onset of status epilepticus, mice were injected with two subcutaneous injections of diazepam $(10 \mathrm{mg} / \mathrm{kg})$ spaced $10 \mathrm{~min}$ apart and returned to their normal housing environment with food and water ad libitum. Sterile Ringer's solution was injected subcutaneously two to three times as needed to maintain the mice at their pretreatment body weight. Mice that did not enter status epilepticus within $1 \mathrm{~h}$ after pilocarpine treatment were excluded from the study. NestinCreER ${ }^{\mathrm{T} 2}:: \mathrm{DTr}^{+/-}:: \mathrm{GFP}^{+/-}$and NestinCreER ${ }^{\mathrm{T} 2}:: \mathrm{DTr}^{-1-}::$ $\mathrm{GFP}^{+/-}$littermates that successfully entered and survived status epilepticus were selected to receive either DT (List Biological Laboratories, catalog \#150, $40 \mu \mathrm{g} / \mathrm{kg}$, i.p.) or saline treatment. Littermates were distributed among treatment groups and groups were balanced by sex; otherwise, animals were assigned randomly. Beginning the third day after status epilepticus, mice received once-daily injections of their respective treatment for $5 \mathrm{~d}$ for a total of 5 doses.

EEG electrode implantation. Between 15 and 17 weeks of age (7-9 weeks after status epilepticus), mice were implanted with cortical electrodes for EEG monitoring (Castro et al., 2012). Mice were anesthetized with $4.0 \%$ isoflurane in $1.5 \%$ oxygen, transferred to a stereotaxic frame, and maintained at $0.8-1.5 \%$ isoflurane for the duration of the surgery. Without damaging the dura, 2 burr holes were drilled in the skull $1.5 \mathrm{~mm}$ anterior to lambda and $1.5 \mathrm{~mm}$ left and right of the sagittal suture. The two leads of the single channel wireless EEG transmitter (TA11ETA-F10; Data Sciences International) were placed between the skull and dura, with one lead through each burr hole. The wireless transmitter was placed subcutaneously behind the nape of the neck. A screw was attached to the base of the skull and dental cement was applied to secure the entire assembly in place. Cutaneous tissue was sealed together with GLUture (Abbott Laboratories) above the dental cement skull cap and subsequently sutured. Mice recovered from surgery for $\sim 30 \mathrm{~min}$ in a $30^{\circ} \mathrm{C}$ incubator before beginning continuous video/EEG monitoring. A timeline depicting the treatment paradigm is provided in Figure 1.

Constant video-EEG monitoring and analysis. After recovery from surgery, mice were housed in individual cages placed on top of wireless receiver plates (RPC1; Data Sciences International). EEG activity was recorded using the wireless video/EEG telemetry system (DATAQUEST A.R.T.), which provides an accurate readout of all frequencies between 1 and $200 \mathrm{~Hz}$. Video footage (Axis 221; Axis Communications) was synchronized with the EEG data. Mice were monitored continuously by video/EEG for up to 4 weeks. Seizure frequency and duration were determined using Neuroscore version 2.1.0 software (DSI) by a reviewer blinded to the treatment conditions. Seizures were defined as a sudden onset of high-amplitude activity with changing amplitude and frequency over the course of the event and a duration $>10 \mathrm{~s}$. Seizure onset was defined by high-amplitude firing $(>2 \times$ background) with a frequency $>1 \mathrm{~Hz}$. Seizure termination was defined by a return to baseline activity. Video data were used to exclude movement artifacts and to assess behavioral seizure severity (Racine, 1972). The average number of seizure clusters was also determined. Seizure clusters were defined as two or more seizures occurring within a $48 \mathrm{~h}$ period, with at least $48 \mathrm{~h}$ of seizure-free activity before and after the cluster. In addition, the number of isolated seizures (i.e., seizures not associated with a seizure cluster) was quantified. Therefore, isolated seizures included all seizures that occurred with at least $48 \mathrm{~h}$ of seizure-free activity before and after the seizure. The total number of clusters and isolated seizures was normalized to the total number of recording days for each individual animal. Data are presented as the number of events per week.

Histology. Mice were anesthetized with pentobarbital and transcardially perfused with heparinized PBS solution $(1 \mathrm{U} / \mathrm{ml})$, followed by $2.5 \%$ paraformaldehyde (PFA) with $4 \%$ sucrose in PBS. Brains were excised, fixed overnight in $2.5 \%$ PFA with $4 \%$ sucrose in PBS, and cryoprotected in $10 \%, 20 \%$, and $30 \%$ sucrose in PBS each for a minimum of $24 \mathrm{~h}$. Brains were snap-frozen in 4-methylbutane chilled to $-25^{\circ} \mathrm{C}$ and stored at $-80^{\circ} \mathrm{C}$ until sectioning. Brains were sectioned coronally at a thickness of $60 \mu \mathrm{m}$ using a cryostat maintained at $-20^{\circ} \mathrm{C}$. Sections were thawed in PBS, slide mounted, air dried, and stored at $-80^{\circ} \mathrm{C}$. Sections were stained with the following primary antibodies: goat anti-HBEGF (to label DTr; R\&D Systems, 1:250, RRID: AB_2114598; Vukovic et al., 2013), rabbit anti-Prox1 (Sigma-Aldrich, 1:1000, RRID: AB_1079691; Murphy et al., 2012), chicken anti-GFP (Abcam, 1:500, RRID: AB_300798; Walter et al., 2007), rabbit anti-ZnT3 (Synaptic Systems, 1:2000, RRID: AB_2189664; McAuliffe et al., 2011), goat anti-doublecortin (Santa Cruz Biotechnology, 1:250, RIDD: AB_2088491; Walter et al., 2007), rabbit anti-GluR2/3 
(Millipore, 1:100, RRID: AB_310741; Hester and Danzer, 2013), mouse anti-NeuN (Millipore, 1:400, RRID: AB_2298772; Pun et al., 2012), mouse anti-GFAP (Millipore, 1:250, RRID: AB_94844; Singh et al., 2015), rabbit anti-Ibal (Synaptic Systems, 1:1000; Hester et al., 2016), and mouse anti-Sox2 (Cell Signaling Technology, 1:200, RRID: AB_ 10560516; Pai et al., 2015). Secondary antibodies used were as follows: donkey anti-rabbit 488, donkey anti-goat 594, donkey anti-rabbit 647 , donkey anti-mouse 647 , goat anti-rabbit 488 , goat anti-chicken 488 , goat anti-rabbit 594, and goat anti-mouse 647 (Life Technologies, 1:750). Sections were dehydrated in serial alcohol washes, cleared in xylenes, and hard mounted with Krystalon mounting medium (EMD Millipore). For all immunostaining protocols, a subset of sections were stained using all reagents except the primary antibody to identify and exclude nonspecific binding of the secondary antibody.

Percentage DTr expression. To determine the percentage of DTrexpressing dentate granule cells within the granule cell body layer, sections from the dorsal hippocampus were immunostained for DTr and prospero homeobox 1 (Prox 1$)$. Image stacks ( $10 \mu \mathrm{m}$ depth, $0.5 \mu \mathrm{m}$ step) were collected from the midpoint of the upper blade $(1.8 \mathrm{~mm}$ posterior of bregma, image size $210 \times 210 \mu \mathrm{m}$ ) from the left and right hemispheres from 1 tissue section (2 hippocampi per animal) using a 3024 Nikon A1Rsi inverted microscope (software RRID: SCR_014329) with a $60 \times$ water objective [numerical aperture $(\mathrm{NA})=1.27,512 \times 512$ pixel density, image size $210 \times 210 \mu \mathrm{m}]$. Confocal image "stacks" were imported into Imaris software (RRID: SCR_007370). The number of Prox1expressing dentate granule cells was quantified using an automated detection method that identifies and counts fluorescent "spots" present in the image stack. Minimum fluorescent intensity and size criteria $(>4.14$ $\mu \mathrm{m})$ were used for the automated screening. Automated counts were then reviewed by an investigator blinded to treatment group to remove false-positives and to identify false-negatives. The reviewer then determined the number of identified Proxl-positive granule cells that coexpressed DTr. Percentage DTr was calculated using the following formula: (number DTr-and Prox1-coexpressing cells in sample/number of Prox1-expressing cells in sample) $\times 100$.

Cell counts. Cell counts to assess granule cell number in the cell body layer and hilus (Prox1), immature granule cell number (doublecortin), and mossy cell number (GluR2/3) were completed from confocal image stacks through the $z$-depth of the tissue. All cell counts were conducted with images collected using a 3024 Nikon A1Rsi inverted microscope (software RRID: SCR_014329) with a $60 \times$ water objective (NA $=1.27$, $512 \times 512$ pixel density, image size $210 \times 210 \mu \mathrm{m})$. For doublecortin, left and right hemispheres from one brain section were counted (bregma $=$ $-1.4 \mathrm{~mm}$ ), giving a total sample of two hippocampi per animal. Prox1 and GluR2/3 counts were collected from the left and right hemispheres of two brain sections (Prox1: bregma $=-1.8 \mathrm{~mm}$, GluR2/3: bregma $=$ $-2.5 \mathrm{~mm}$ ), for a total of four hippocampi per animal. A larger sample was used for these latter measures to avoid undersampling errors resulting from the low number of cells per section. All cell counts were completed using a modification of the optical dissector method (Howell et al., 2002; Hofacer et al., 2013). Using this methodology, cells cropped at the surface of the image stack or at two predetermined adjacent sides in the $X-Y$ plane are excluded. All counts were completed by a reviewer blinded to treatment conditions.

The number of correctly located (normotopic) granule cells and hilar ectopic granule cells was determined using two Prox1-immunostained sections/animal. The 2 sections were selected from dorsal hippocampus (bregma $-1.8 \mathrm{~mm}$ ). Confocal image stacks ( $20 \mu \mathrm{m}$ depth, $1.0 \mu \mathrm{m}$ step) of large tile scans were generated so that the entire dentate hilus was imaged. Image stacks were imported into Neurolucida software (RRID: SCR_001775) for analysis of hilar ectopic granule cells. In this analysis, Prox ${ }^{+}$ectopic granule cells were counted. A cell was considered ectopic if it was at least $20 \mu \mathrm{m}$ from the granule cell body layer-hilar border. To determine the number of granule cells in the granule cell body layer, confocal images were imported into Imaris software (RRID: SCR_007370). The total number of Prox1-expressing dentate granule cells present in the image was quantified using the fluorescent "spots" automated detection method. Minimum fluorescent intensity and size criteria $(>4.14 \mu \mathrm{m})$ were used and counts were reviewed by an investi- gator blinded to treatment group to remove false-positives and to identify false-negatives. Ectopically located cells present in the hilus were also removed for this analysis.

To quantify the number of immature granule cells, 1 section from each animal from $\sim 1.4 \mathrm{~mm}$ posterior to bregma was stained for doublecortin. Confocal image stacks (20 $\mu \mathrm{m}$ depth, $1.0 \mu \mathrm{m}$ step) of tile scans containing the entire granule cell body layer were generated. Image stacks were imported into Neurolucida software (RRID: SCR_001775) and doublecortin-positive cell bodies were counted.

Mossy cells were quantified using sections immunostained with antibodies against glutamate receptor $2 / 3$ subunits (GluR2/3). Image stacks (20 $\mu \mathrm{m}$ depth, $1.0 \mu \mathrm{m}$ step) of tile scans of the entire hilus were collected from 2 tissue sections, both of which were $\sim 2.5 \mathrm{~mm}$ posterior to bregma. GluR2/3 stains excitatory neurons including mossy cells and hilar ectopic granule cells. Mossy cells were distinguished from ectopic granule cells by their larger soma size ( $\sim 30-40 \mu \mathrm{m}$ vs $\sim 7-12 \mu \mathrm{m}$ diameter, respectively; Fujise and Kosaka, 1999; Jiao and Nadler, 2007). Only cells with a diameter $>20 \mu \mathrm{m}$ were counted as mossy cells. Cell counts were completed using Imaris software (RRID: SCR_007370).

Mossy fiber sprouting. To determine the extent of mossy fiber sprouting, one section from each animal from the dorsal hippocampus was immunostained for zinc transporter 3 (ZnT3). Confocal optical sections were collected at the midpoints of the upper and lower blades of the left and right dentate gyri (2.4 mm posterior to bregma) using a DMI6000 Leica SP5 inverted microscope (software RRID: SCR_013673) with a $63 \times$ oil objective $(\mathrm{NA}=1.4,2048 \times 2048$ pixel density, image size $248 \times$ $248 \mu \mathrm{m})$. All images were taken $2-3 \mu \mathrm{m}$ beneath the surface of the tissue to ensure equivalent antibody penetration. Images were imported into Neurolucida software (RRID: SCR_001775) and the area of the inner molecular layer occupied by $\mathrm{ZnT}^{+}{ }^{-}$-immunoreactive puncta was quantified using automated object detection (Pun et al., 2012; Hester and Danzer, 2013). The software was set to exclude all objects with a diameter $<0.5 \mu \mathrm{m}$, the minimum size of mossy fiber terminals (Danzer et al., 2008). The automated analysis was reviewed for accuracy by an investigator blinded to the treatment conditions. Percentage mossy fiber sprouting was calculated using the following formula: (area of $\mathrm{Znt} 3^{+}$ immunoreactivity/area of inner molecular layer examined) $\times 100$.

Reactive astrocytosis and microgliosis. Sections were immunostained for glial fibrillary acidic protein (GFAP) and ionized calcium-binding adaptor molecule 1 (Iba1). Confocal image stacks (10 $\mu \mathrm{m}$ depth, 0.25 $\mu \mathrm{m}$ step) were collected from the hilar regions of the left and right hemispheres from one section from each animal $(2.7 \mathrm{~mm}$ posterior to bregma). Image stacks were imported into Neurolucida software (RRID: SCR_001775) for measurement of astrocyte and microglia soma maximum profile area. Only cells with somas fully contained within the tissue section were scored. Five astrocytes and five microglia per hemisphere were selected randomly for analysis (for a total of 10 cells of each type per animal), as described previously (Kang et al., 2014; Hester et al., 2016; Smith et al., 2016). Data were averaged before statistical analysis.

Statistics. All statistical analyses were performed using SigmaPlot software (RRID: SCR_003210). A total of 161 animals were generated to be used for multiple studies. Of these animals, $24.2 \%$ did not enter status, $10.6 \%$ died in status, and $11.2 \%$ were moribund after status and were killed. Of the 87 mice that successfully entered and survived status (54\%), 48 were assigned randomly for use in the present study. Only animals that were implanted and underwent video/EEG monitoring for a minimum of $10 \mathrm{~d}$ were included in the study, leaving a total of 33 experimental mice (15 animals were lost to surgical complications, electrode failures, or space limitations on recording slots). Final animal numbers and groupings were as follows: (1) pilocarpine-treated NestinCreER ${ }^{\mathrm{T} 2}:: \mathrm{DTr}^{+/-}::$ $\mathrm{GFP}^{+/-}$receiving DT, $n=10$ (4 male, 6 female; referred to as "SE-ablation"); (2) pilocarpine-treated NestinCreER ${ }^{\mathrm{T} 2}:: \mathrm{DTr}^{-1-}:: \mathrm{GFP}^{+/-}$ receiving DT, $n=6$ (4 male, 2 female; DTr negative $+\mathrm{DT})$; (3) pilocarpinetreated NestinCreER ${ }^{\mathrm{T} 2}:: \mathrm{DTr}^{+/-}:: \mathrm{GFP}^{+/-}$receiving saline, $n=14$ (9 male, 5 female; DTr positive + saline); and (4) pilocarpine-treated Nestin $\mathrm{CreER}^{\mathrm{T} 2}:: \mathrm{DTr}^{-1-}:: \mathrm{GFP}^{+/-}$receiving saline $n=3(2$ male, 1 female; $\mathrm{DTr}$ negative+ saline). One animal (female NestinCreER ${ }^{\mathrm{T} 2}:: \mathrm{DTr}^{-1-}:: \mathrm{GFP}^{+/-}$ receiving DT) was found deceased $20 \mathrm{~d}$ into the video/EEG recording period. This mouse was included for all EEG readouts and excluded from all histo- 


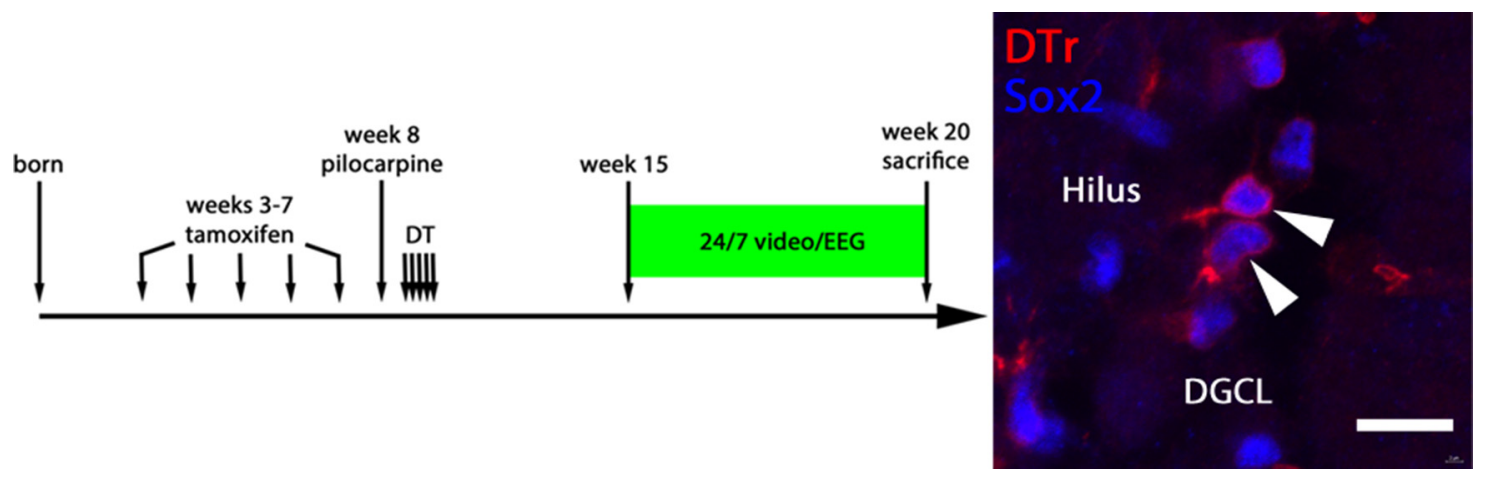

Figure 1. Tamoxifen induces DTr expression in neural progenitor cells. Top, Timeline detailing the animal treatment used in this protocol. Mice were given five weekly tamoxifen injections beginning on postnatal day 21. One week after the last tamoxifen injection, mice underwent pilocarpine-induced status epilepticus. Three days later, mice received once-daily injections of DT or saline for a total of $5 \mathrm{~d}$. Mice were implanted 7 weeks after status epilepticus and underwent continuous video-EEG monitoring for 4 weeks. Bottom, DTr (red) expression and Sox2 (blue) expression 1 week after the last tamoxifen injection. Type 2 progenitor cells expressing DTr are indicated by the white arrowheads. DGCL, Dentate granule cell layer. Scale bar, $10 \mu \mathrm{m}$.

logical analyses because the brain was not recovered. Two animals (a female NestinCreER ${ }^{\mathrm{T} 2}:: \mathrm{DTr}^{+/-}:: \mathrm{GFP}^{+/-}$receiving DT and a male Nestin $\mathrm{CreER}^{\mathrm{T} 2}:: \mathrm{DTr}^{+/-}:: \mathrm{GFP}^{+/-}$receiving saline) exhibited zero seizures during the recording period and thus could not be included in the seizure duration and severity analyses. For statistical analysis of histological measures, repeat measures from the same animal were averaged, such that $n=$ animal number, not the number of hippocampi examined. Parametric tests were used for data that met assumptions for normality and equal variance, whereas nonparametric alternatives were used for data that violated either assumption. Individual tests used are noted in the text. All $t$ tests are two-tailed and $p \leq 0.05$ was accepted as significant.

No statistical differences were found between sexes for all parameters analyzed (data not shown); therefore, males and females were grouped within their respective treatments. ANOVA on ranks revealed no differences among the "DTr-positive + saline," "DTr-negative + DT," and "DTr-negative + saline" groups for the following nonparametric datasets: seizure frequency $(p=0.399)$, severity $(p=0.796)$, duration $(p=$ $0.577)$, duration range ( $p=0.639)$, shortest seizure $(p=0.237)$, longest seizure $(p=0.772)$, seizure events in seizure clusters $(p=0.203)$, percentage of seizures not in a cluster $(p=0.427)$, presence of ectopic cells $(p=0.401)$, mossy cell density $(p=0.060)$, and mossy fiber sprouting $(p=0.858)$. One-way ANOVA revealed no differences between these groups for the following parametric datasets: presence of normotopic granule cells $(p=0.297)$, neurogenesis $(p=0.800)$, astrocyte area $(p=$ $0.750)$, microglia area $(p=0.715)$, and number of observed seizure clusters $(0.766)$. Therefore, these groups were merged together and will be referred to as "SE-control." Final video/EEG recording periods were as follows: (1) SE-control: mean $=22.9 \pm 6.5 \mathrm{~d}$, range $=10-32 \mathrm{~d}$ and (2) SE-ablation: mean $=25.4 \pm 5.5 \mathrm{~d}$, range $=14-31 \mathrm{~d}$.

Figure preparation. All figures were prepared using Adobe Photoshop Elements 12. Color, brightness, and contrast were adjusted to enhance image details. Identical adjustments were made to all images meant for comparison. Parametric data are presented in bar graphs, with error bars indicating SEM. Nonparametric data are presented in box plots. Lines extending from the top and bottom of each box indicate the $10^{\text {th }}$ and $90^{\text {th }}$ percentile. Data points not found between the $10^{\text {th }}$ and $90^{\text {th }}$ percentiles are marked by black dots. Box plots that lack lower reaching lines (see Fig. $2 B, C$ ) do not have data points lower than the $75^{\text {th }}$ percentile. Box plots that lack a middle bar do not have data points lower than the median (see Fig. 2B).

\section{Results}

NestinCreER ${ }^{\mathrm{T} 2}: \mathrm{DTr}^{+/-}:: \mathrm{GFP}^{+/-}$mice express DTr robustly within newly generated dentate granule cells and their progenitors

NestinCreER ${ }^{\mathrm{T} 2}:: \mathrm{DTr}^{+/-}:: \mathrm{GFP}^{+/-}$mice killed 1 week after the tamoxifen administration exhibited DTr expression within a subset of cells localized within the inner third of the granule cell body layer. DTr expression was evident among cells immunopo- sitive for Sox2 (Fig. 1), consistent with type one and type two granule cell progenitors. DTr expression was also observed within small numbers of hippocampal and cortical astrocytes, corpus callosum oligodendrocytes, and midbrain neurons (data not shown).

\section{Prophylactic ablation of newly generated granule cells reduces seizure frequency}

Beginning $3 \mathrm{~d}$ after pilocarpine-induced status epilepticus, mice were treated with DT to ablate granule cells generated during the 5 week period before status, as well as DTr-labeled progenitors that would remain active after status. Seven weeks later, a 4 week period of continuous video-EEG monitoring was begun. Ablation of newly generated granule cells reduced median seizure frequency by $50 \%$ relative to epileptic control groups that did not undergo cell ablation treatment [SEcontrol, $n=23$ mice, median $=0.727$ [0.519-0.950] events per day; SE-ablation, $n=10$ mice, median $=0.439$ [0.1310.715 ] events per day; $p=0.042$, Mann-Whitney rank-sum test (RST); Fig. 2A].

\section{Granule cell ablation reduces seizure clustering}

In the pilocarpine model of epilepsy, seizures often occur in clusters, interspersed by days with no seizure activity. To determine whether granule cell ablation disrupts this clustering, seizures were categorized as either being part of a cluster or not in a cluster. SE-ablation mice experienced significantly more isolated seizures than SE-control mice (SE-control, $n=23$ mice, median $=0.0[0.0-0.3]$ isolated seizures per week; SE-ablation, $n=$ 10 , median $=0.4[0.0-1.0]$ isolated seizures per week; $p=0.032$, Mann-Whitney RST; Fig. 2B). The total number of seizure clusters was unchanged between groups (SE-control, $n=23$ mice, median $=0.7[0.6-0.8]$ clusters per week; SE-ablation, $n=10$, median $=0.7[0.0-0.8]$ clusters per week; $p=0.366$, MannWhitney RST; Fig. 2C). The average number of seizures within each cluster was also unchanged between groups (SE-control, $n=22$ mice, median $=7.2[3.9-12.8]$ seizures per cluster; SEablation, $n=7$, median $=5.0[2.4-9.5]$ seizures per cluster; $p=$ 0.296, Mann-Whitney RST; Fig. 2D). Mice exhibiting no seizure clusters (SE-control, $n=1$; SE-ablation, $n=3$ ) were omitted for this latter analysis.

\section{Granule cell ablation increases seizure duration}

An unexpected finding of the present study was that granule cell ablation increased seizure duration significantly. Seizures were 
A

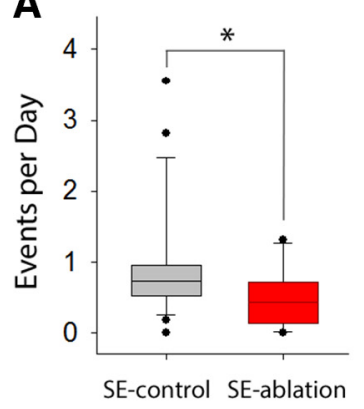

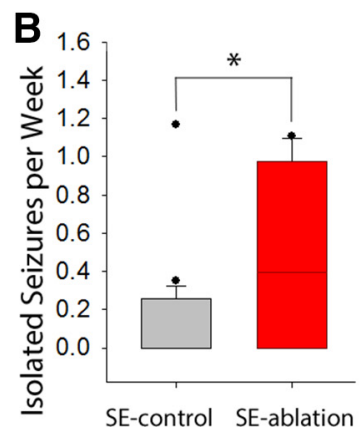

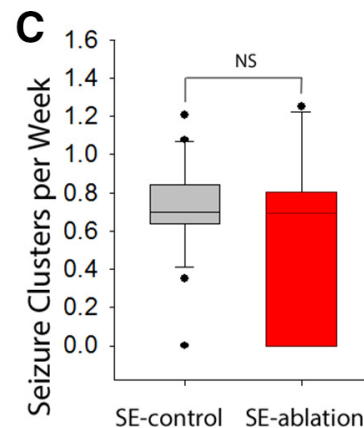

D

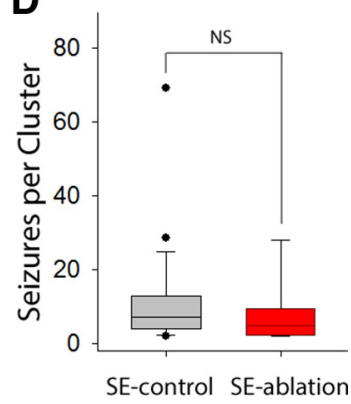

Figure 2. Seizure frequency is reduced in SE-ablation mice. Measures of seizure frequency and clustering in SE-control (gray bars) and SE-ablation (red bars) mice. $A$, Average number of seizure events per day (SE-control: $n=23$, SE-ablation: $n=10$, Mann-Whitney RST, $p=0.042$ ). $\boldsymbol{B}$, Number of isolated seizures per week, defined as seizures that were preceded by and followed by a minimum 48 h seizure-free period (SE-control: $n=23$, SE-ablation: $n=10$, Mann-Whitney RST, $p=0.032$ ). C, Number of clusters per week (SE-control: $n=23$, SE-ablation: $n=10$, Mann-Whitney RST, $p=0.366$ ). D, Average number of seizures per cluster (for this measure, animals that did not exhibit any seizure clusters were omitted; SE-control: $n=22, \mathrm{SE}-\mathrm{ablation}: n=7$, Mann-Whitney RST, $p=0.296)$. Data are represented as mean \pm SEM. ${ }^{*} p \leq 0.05$.
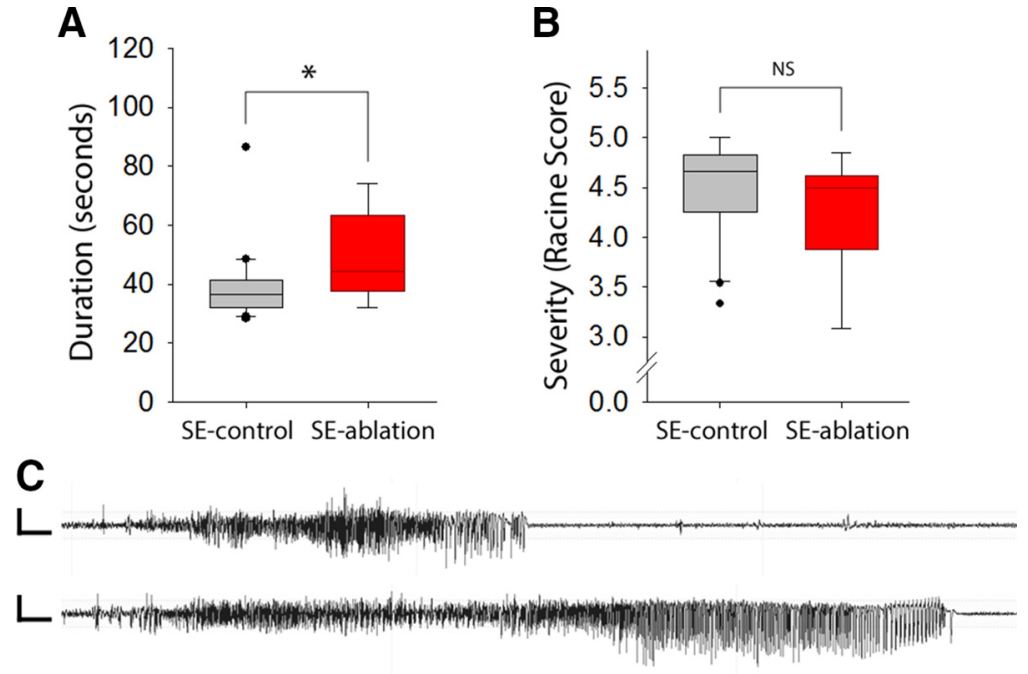

Figure 3. Seizure duration is increased in SE-ablation mice. Measures of seizure duration and behavioral seizure severity in SE-control (gray bars) and SE-ablation (red bars) mice. $A$, Average seizure duration (SE-control: $n=22$, SE-ablation: $n=9$, Mann-Whitney RST, $p=0.020$ ). $B$, Average seizure severity as determined by the Racine scale (SE-control: $n=22$, SE-ablation: $n=9$, Mann-Whitney RST, $p=0.240$ ). Data are represented as mean \pm SEM. ${ }^{*} p \leq 0.05$. C, Sample EEG tracings from an SE-control mouse (top) and an SE-ablation mouse (bottom). Scale bar, $400 \mu \mathrm{V}, 3 \mathrm{~s}$.

almost 20\% longer in the SE-ablation group, increasing from a median of 36.4 to $44.3 \mathrm{~s}$ (SE-control, $n=22$ mice, median $=36.4$ [31.96-41.3] seconds; SE-ablation, $n=9$, median $=44.3[37.7-$ 63.17] seconds; $p=0.020$, Mann-Whitney RST; Fig. $3 A, C)$. No differences in behavioral seizure severity were found (SE-control, $n=22$ mice, median Racine score of 4.7 [4.3-4.8]; SE-ablation, $n=9$, median Racine score of 4.5 [3.9-4.6]; $p=0.240$, MannWhitney RST; Fig. $3 B$ ), perhaps reflecting the tendency in both groups for seizures to reach maximum behavioral scores of class IV or V on the Racine scale (Racine, 1972).

To begin to investigate why reduced seizure frequency might lead to an increase in seizure duration, we first queried whether seizure duration changed over time in SE-control animals or if it was constant. Strikingly, SE-control animals showed clear variations in seizure duration over time (Fig. $4 A, B$ ). Seizure duration varied by an average of $28.5 \pm 5.6 \mathrm{~s}$ between nadir and zenith, from $27.9 \pm 2.3$ to $56.4 \pm 5.8 \mathrm{~s}$ (averages of single shortest seizure/mouse \pm SEM to the single longest seizure). Further analysis of SE-control mice revealed that the mean duration of the first 2 seizures within a cluster was significantly longer than seizures that occurred later in the cluster (first 2 seizures in cluster: LSM =
$37.4 \pm 1.5 \mathrm{~s}$; all other seizures: LSM = $35.1 \pm 1.5 \mathrm{~s} ; p=0.004$, differences of LSMs using a mixed-effect model analysis with random animal effect and random cluster effect nested within each animal; Fig. $4 A, B$, red arrows). Seizure duration in SE-ablation animals also varied, ranging from $33.9 \pm 3.1$ to $67.9 \pm 6.9$ s. In SE-ablation animals, however, the first 2 seizures were not significantly longer than later seizures in the cluster (first two seizures in cluster: $\mathrm{LSM}=50.9 \pm 4.7 \mathrm{~s}$; all other seizures: $\mathrm{LSM}=48.0 \pm 4.8 \mathrm{~s} ; p=$ 0.109 , differences of LSM using mixedeffect model analysis with random animal effect and random cluster effect nested within each animal; Fig. 4C,D). These findings suggest the existence of homeostatic mechanisms that act to limit seizure duration during seizure clusters. If correct, the increased incidence of isolated seizures in SE-ablation mice (Figs. 2B, $4 C, D)$ could be responsible for the paradoxical increase in seizure duration.

\section{DT treatment effectively ablates DTr-expressing cells}

After cessation of seizure monitoring, mice were killed and brains were removed for histological analysis. To confirm that DT treatment effectively ablated newly generated granule cells, DTr expression was compared in DTr-expressing mice treated with DT (SE-ablation; $n=10$ ) or saline (DTr-positive + saline; $n=14$ ). DTr expression among DTr-positive + saline mice was $17.9 \pm$ $1.1 \%$, reflective of expression among neurons generated both during the end of postnatal development and adulthood (Pun et al., 2012). Percentage DTr expression among Prox1-positive dentate granule cells was significantly reduced in DT-treated mice $(p<0.001$, Student's $t$ test; Fig. 5), indicating that DT treatment ablated newly generated neurons.

\section{DT treatment reduces the number of ectopic and normotopic granule cells}

The cell ablation experiments conducted here were designed to test the hypothesis that abnormally integrated, newly generated granule cells contribute to epileptogenesis. It was important, therefore, to establish that ablation was effective at reducing ab- 
normal cells. Hilar ectopic granule cells are a key granule cell abnormality implicated in promoting seizures (Scharfman et al., 2000; Scharfman et al., 2003; Zhan et al., 2010; Cameron et al., 2011; Hester and Danzer, 2013; Myers et al., 2013; Althaus et al., 2015; Scharfman and Myers, 2016). To confirm effective ablation of this cell population, ectopic granule cells were immunostained with the granule-cellspecific marker Prox1 in all animals. The median number of Prox $1^{+}$cells localized in the hilus was reduced by $50 \%$ relative to controls (SE-control, $n=22$ mice; SEablation, $n=10$; $p=0.024$, Mann-Whitney RST; Fig. 6), confirming effective ablation of these aberrant neurons.

The number of granule cells located in the granule cell body layer was also quantified to determine whether cell ablation affected the overall granule cell number. Results reflect the average number of cells located within a $20-\mu \mathrm{m}$-thick section of the dorsal hippocampus. We found the total number of granule cells to be reduced in SE-ablation mice compared with controls (SE-control, $n=22$ mice; SE-ablation, $n=10 ; p=0.026$, Student's $t$ test; Fig. 6), reflecting ablation of newborn granule cells that correctly integrated into the granule cell body layer.

\section{Cell ablation does not affect mossy fiber sprouting}

Newly generated granule cells are reported to contribute mossy fiber sprouting in epilepsy (Kron et al., 2010). Mossy fiber sprouting occurs when granule cell mossy fiber axons project into the dentate inner molecular layer. To assess sprouting, sections from each animal were stained for $\mathrm{ZnT3}$, a vesicular transport protein highly expressed in mossy fiber axon terminals (McAuliffe et al., 2011). No differences in ZnT3 immunoreactivity within the inner molecular layer were found between SE-ablation and SEcontrol mice (SE-control, $n=22$ mice; SE-ablation, $n=10 ; p=$ 0.951, Mann-Whitney RST; Fig. 7), indicating that granule cells other than those targeted here underlie mossy fiber sprouting in these animals. These findings are consistent with prior work by Cho et al. (2015) showing that preablation of neurogenesis also fails to block mossy fiber sprouting and work by Althaus et al. (2016) showing that mature cells can also contribute to sprouting.

\section{Cell ablation reduces but does not eliminate neurogenesis}

The ablation strategy used here eliminates a subset of Nestinexpressing progenitor cells, which could lead to a long-term reduction in neurogenesis. Alternatively, because Cre-mediated recombination is not 100\% efficient (Sun et al., 2014), progenitor cells that escape ablation may repopulate the progenitor pool (Ahn and Joyner, 2005). To determine whether ablation leads to a detectable reduction in neurogenesis 11 weeks later, all animals were immunostained with the progenitor cell marker doublecortin. Doublecortin is transiently expressed by 1 - to 2-week-old immature granule cells (Brown et al., 2003), providing a measure of neurogenesis rates in animals a couple weeks before they are killed. The median number of doublecortin-expressing cells was reduced by $50 \%$ in SE-ablation mice relative to controls (SEcontrol, $n=22$ mice; SE-ablation, $n=10 ; p=0.006$, Mann-
Whitney RST; Fig. 8), indicating that neurogenesis is reduced but not eliminated at this time point.

\section{Cell ablation does not affect astrogliosis or microglial activation}

Activation of inflammatory cells (reactive gliosis) occurs after pilocarpine-induced status epilepticus (Garzillo and Mello, 2002; Borges et al., 2003) and after suppression of neurogenesis (Monje et al., 2002; Mizumatsu et al., 2003; Rola et al., 2004). Data suggest that reactive gliosis partially facilitates epileptogenesis (Gibbons et al., 2013; Vezzani et al., 2016); therefore, we investigated whether DT-mediated ablation of newly generated granule cells produced any detectable change in reactive gliosis. Sections were immunostained for the astrocyte marker GFAP and the microglial marker Iba1. Activated astrocytes and microglia exhibit enlarged somas relative to quiescent cells (Saijo and Glass, 2011; Lee and MacLean, 2015). In the present study, soma areas were statistically identical between groups for both cell types, suggesting that cell ablation does not produce a measurable change in brain inflammation (SE-control, $n=22$ mice; SE-ablation, $n=10$; astrocytes: $p=0.896$, Student's $t$ test; microglia: $p=0.699$, Mann-Whitney RST; Fig. 9).

\section{DT treatment does not inhibit mossy cell loss}

Irreversible loss of hilar mossy cells occurs hours after status epilepticus and was not expected to differ between groups. Mossy cells function by regulating synaptic activity in the dentate (Scharfman and Myers, 2012) and data suggest that mossy cell death can lead to hyperexcitability of granule cells during certain conditions (Jinde et al., 2012, but see Ratzliff et al., 2004). To confirm that the results described here cannot be attributed to differences in mossy cell loss, we stained sections from each animal for GluR2/3, a marker for excitatory neurons. Mossy cell density did not differ between groups (SE-control, $n=22$ mice, median $=1.0$ cells/hilus $[0.0-2.6]$; SE-ablation, $n=10$, median $=0.0$ cells/hilus $[0.0-2.0] ; p=0.379$, Mann-Whitney RST). DT treatment did not inhibit mossy cells loss and it can be in- 
DTr positive + saline
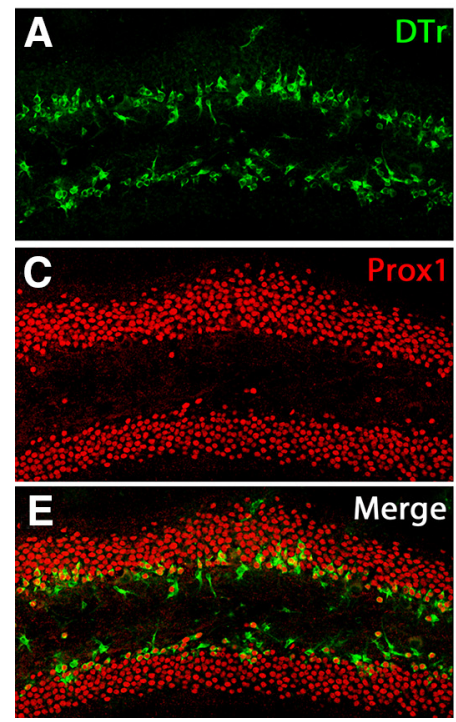

$\operatorname{Tr} \mathbf{B}$

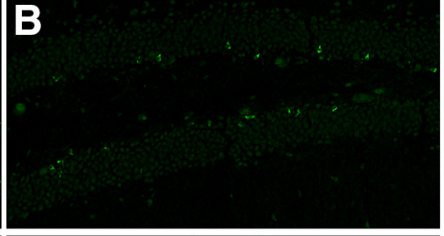

D.
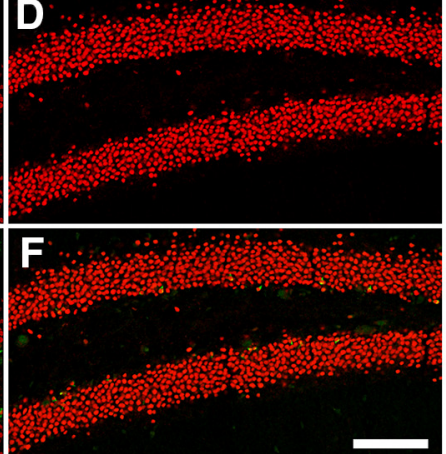

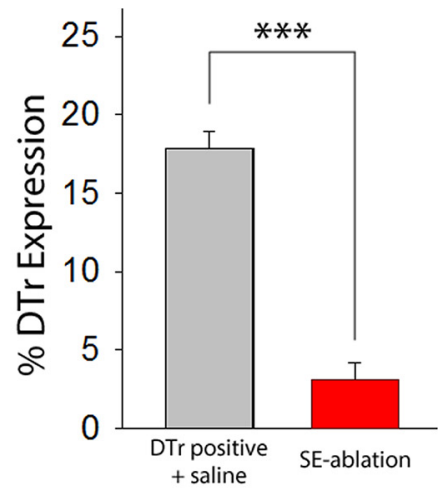

Figure 5. DT effectively ablates DTr-expressing cells. Shown are DTr (green) and Prox1 (red) expression in DTr positive + saline $(\boldsymbol{A}, \boldsymbol{C}, \boldsymbol{E})$ and SE-ablation $(\boldsymbol{B}, \boldsymbol{D}, \boldsymbol{F})$ animals. The graph shows the mean percentage of DTr expression among Prox1 positive dentate granule cells in DTr positive + saline (gray bar) and SE-ablation (red bar) mice (DTr positive + saline: $n=14$, SE-ablation: $n=$ 10$, Student's $t$ test, $p<0.001)$. Data are represented as mean \pm SEM. ${ }^{* * *} p \leq 0.001$. Scale bar, $100 \mu \mathrm{m}$.

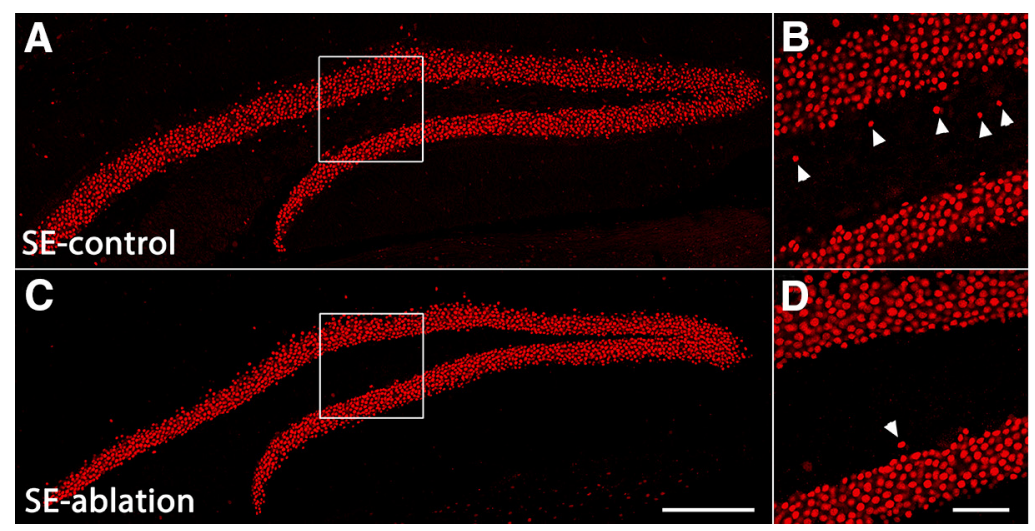

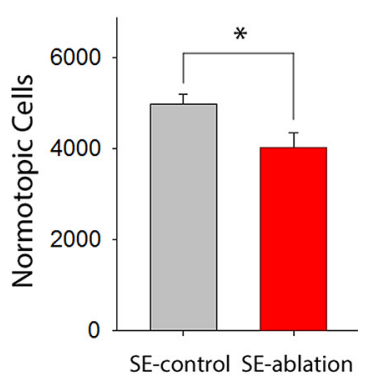

Figure 6. Ablation treatment reduces the number of ectopically and normotopically located granule cells. Prox1 expression in SE-control $(\boldsymbol{A})$ and SE-ablation $(\boldsymbol{C})$ mice. $\boldsymbol{B}, \boldsymbol{D}$, Right, Enlargements of the white boxes in $\boldsymbol{A}$ and $\boldsymbol{C}$, respectively. Graphs depict the total number of ectopic and normotopic dentate granule cells within a $20 \mu \mathrm{m}$ section of the dorsal hippocampus from $S E$-control mice (gray) and SE-ablation mice (red) (SE-control: $n=22$, SE-ablation: $n=10$, Mann-Whitney RST, $p=0.013$ ). Data are represented as mean \pm SEM. ${ }^{*} p \leq 0.05$. Scale bars: $\boldsymbol{A}, \boldsymbol{C}, 200 \mu$ m; B, D, $50 \mu \mathrm{m}$.

ferred that the severity of status epilepticus was comparable between treatment groups.

\section{Discussion}

Here, we used a transgenic strategy to ablate newly generated dentate granule cells and actively dividing neural progenitor cells selectively $3 \mathrm{~d}$ after pilocarpine-induced status epilepticus. This treatment decreased seizure frequency by $50 \%$. Paradoxically, the treatment also increased seizure duration. Careful analyses of seizure durations over time suggest that this may be an unavoidable consequence of reducing seizure incidence because seizure clustering was associated with reduced seizure duration and isolated seizures were more common in treated mice. Cell ablation treatment reduced hilar ectopic granule cells, consistent with the interpretation that these abnormal neurons are pro-epileptogenic. In contrast, cell ablation did not affect mossy fiber sprouting, mossy cell loss, or hypertrophy of hippocampal astrocytes and microglia, suggesting that these changes cannot account for the reduction in seizure frequency. Together, these findings provide new support for the hy- pothesis that abnormal integration of newly generated granule cells promotes epileptogenesis.

\section{Dentate gate hypothesis for temporal lobe epilepsy}

Granule cells normally act as a "gate" to limit information flow through the hippocampal circuit (Heinemann et al., 1992; Behr et al., 1998; Ang et al., 2006). Loss of this gating function may contribute to epileptogenesis (Hsu, 2007; Fujita et al., 2014; KrookMagnuson et al., 2015). The present study tests a key aspect of this hypothesis, namely, that rewiring of the dentate gyrus by newly generated granule cells increases hippocampal excitability and impairs the dentate gate. The efficacy of ablating these cells in reducing seizure frequency supports this hypothesis.

Elimination of hilar ectopic granule cells may be pivotal for the seizure reduction observed here. Ectopic granule cells are hyperexcitable (Scharfman et al., 2000; Scharfman et al., 2003; Zhan et al., 2010; Cameron et al., 2011; Myers et al., 2013; Althaus et al., 2015; Scharfman and Myers, 2016) and their numbers correlate with seizure frequency in epileptic animals (Hester and 
Danzer, 2013). Although not assessed here, elimination of other abnormal granule cells, such as those with basal dendrites, may also contribute to the observed effect. Finally, we observed no reduction in mossy fiber axon sprouting, further bolstering recent suggestions that this particular abnormality may not play a significant role in seizure occurrence (Buckmaster, 2014).

An alternative possibility is that reduced neurogenesis per se, rather than selective removal of abnormal cells, is critical for the observed effect. Although not assessed directly here, we predict that DT treatment reduced neurogenesis dramatically in the days after treatment. The relatively modest reduction evident 10 weeks later likely reflects restoration of the neurogenic niche by unaffected progenitors. Newborn neurons exhibit many unique features, including enhanced long-term potentiation (SchmidtHieber et al., 2004). Loss of these neurons, therefore, might be important for mitigating epileptogenesis.

\section{Removing newly generated cells at a clinically relevant time after status reduces seizure frequency}

The present study provides a novel test of the role of newborn granule cells in epilepsy for three key reasons. First, we were able to remove newly generated cells after status epilepticus, which prevents the treatment from confounding interpretation by altering the severity of the insult. Reducing neurogenesis before kainic-acid-induced status epilepticus, for example, enhances sensitivity to the convulsant (Iyengar et al., 2015). Removal of newly generated granule cells has been shown to alter long-term potentiation (Singer et al., 2011), which might contribute to the altered kainic acid response. Second, postinsult ablation is more clinically relevant because patients could be treated after an epileptogenic brain injury such as status epilepticus. Finally, using the DT-mediated cell ablation strategy, we removed granule cell progenitors present at the time of status epilepticus, as well as immature granule cells born weeks before the insult. Other antineurogenesis strategies, such as the antimitotic cytosine-b-Darabinofuranoside (Jung et al., 2004) and ganciclovir-thymidine kinase (Cho et al., 2015), are only effective against progenitors, leaving immature granule cells untouched. This difference is important because both immature granule cells born up to 5 weeks before the insult and granule cells born after the insult integrate improperly in the dentate gyrus during epileptogenesis (Jessberger et al., 2007; Walter et al., 2007; Kron et al., 2010; Danzer, 2012). That said, application of antimitotics after status epilepticus still produced $70-75 \%$ reductions in seizure frequency (Jung et al., 2004, 2006), although counts relied on intermittent behavioral monitoring so nonconvulsive seizures would be missed. In contrast, Cho et al. (2015) found that ablating neurogenesis for the 4 week period before status epilepticus reduced seizure frequency by $40 \%$, whereas ablating cells both before and after status was not effective. The latter, paradoxical, result may reflect technical limitations of the cre driver line used; however, the possibility that newborn cells play maladaptive and protective roles in epilepsy cannot be excluded (Danzer, 2015). Encouragingly, a diversity of techniques now implicate granule cell neurogenesis in epilepsy, but additional work is needed to resolve exactly when and where to target treatments.

\section{Reducing seizure frequency may limit homeostatic mechanisms that reduce seizure duration}

An unexpected, but important, finding of this study was that dentate granule cell ablation increased seizure duration. In SE-control mice, seizures rarely lasted $>30-40 \mathrm{~s}$, whereas SEablation mice often had seizures lasting $90 \mathrm{~s}$ or more. Intriguingly, in a subset of SE-control mice, the first or second seizure in a seizure cluster was often significantly longer than all other seizures in the cluster. These observations led us to propose the existence of homeostatic mechanisms that limit seizure duration when seizures occur in rapid succession (as in a cluster). The shift to isolated seizures after SE-ablation would then account for the increased duration of these seizures.

Homeostatic responses to seizure activity have been demonstrated previously. For example, loss of dendritic spines, which mediate excitatory communication with afferent neurons, is common in numerous models of temporal lobe epilepsy (Müller et al., 1993; Swann et al., 2000; Kurz et al., 2008). Corresponding reductions in excitatory synapses might act to limit seizure duration (Tejada et al., 2014; Pai et al., 2015). Studies from the kindling model of epilepsy provide further evidence for seizure-induced homeostatic changes. In the kindling model, the brain is repeatedly stimulated using implanted electrodes to induce brief electrical seizures. Repeated stimulations lead to a persistent reduction in seizure threshold, but not spontaneous seizures. Using this model, it is possible to examine the short- and long-term impacts of a single evoked seizure (without the confounding occurrence of spontaneous seizures). Twenty-four hours after an evoked seizure, granule cell dendrites exhibit reduced spine densities and increased numbers of giant mossy fiber bouton filipodia. These filipodia innervate GABAergic inhibitory interneurons (Acsády et al., 1998), leading to a predicted net increase in inhibition (more filipodia) and a net decrease in excitation (fewer spines). Importantly, 1 month after the evoked seizure, these changes completely dissipated, indicating that, in the absence of ongoing seizure activity, these putative homeostatic changes fade (Danzer et al., 2010; Singh et al., 2013). 

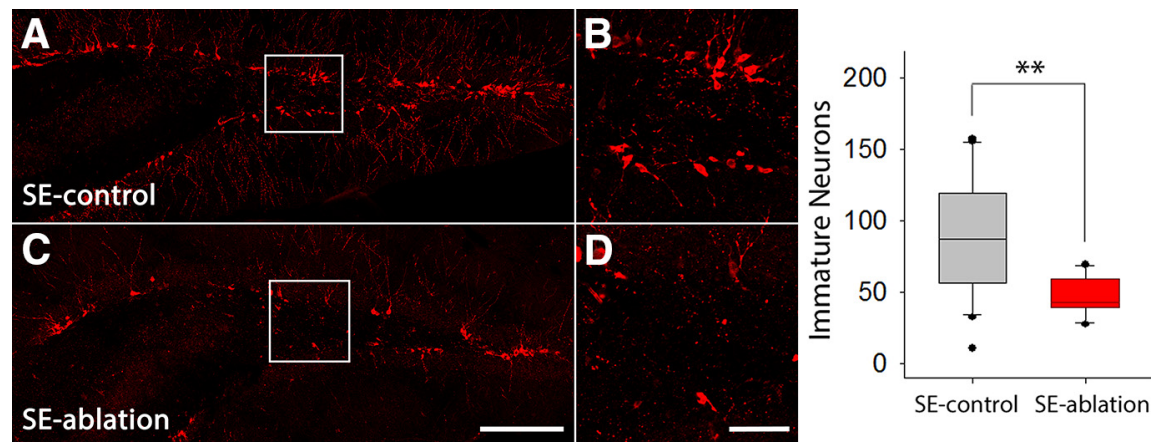

Figure 8. Cell ablation reduces neurogenesis. Doublecortin expression in SE-control $(\boldsymbol{A})$ and SE-ablation ( $\boldsymbol{C}$ ) mice. $\boldsymbol{B}, \boldsymbol{D}$, Right Enlargements of the white boxes in $\boldsymbol{A}$ and $\boldsymbol{C}$, respectively. The graph illustrates the number of doublecortin-expressing immature neurons per dentate section in the dorsal hippocampus of SE-control (gray) and SE-ablation (red) mice (SE-control: $n=22$, SE-ablation: $n=10$, Mann-Whitney RST, $p=0.006)$. Data are represented as mean \pm SEM. ${ }^{* *} p \leq 0.01$. Scale bars: $A, C, 200$ $\mu \mathrm{m} ; \boldsymbol{B}, \boldsymbol{D}, 50 \mu \mathrm{m}$.

\section{SE-control}
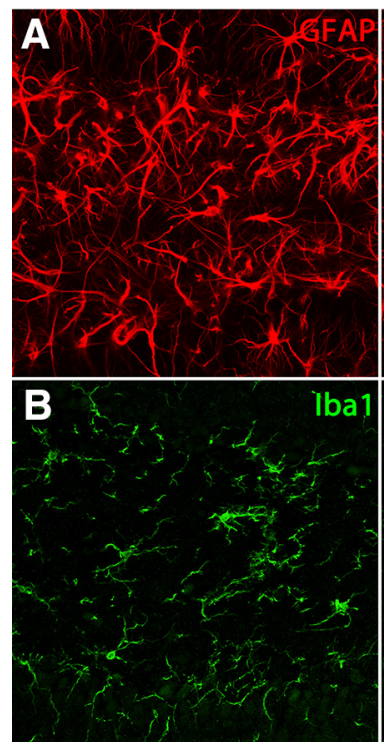

\section{SE-ablation}
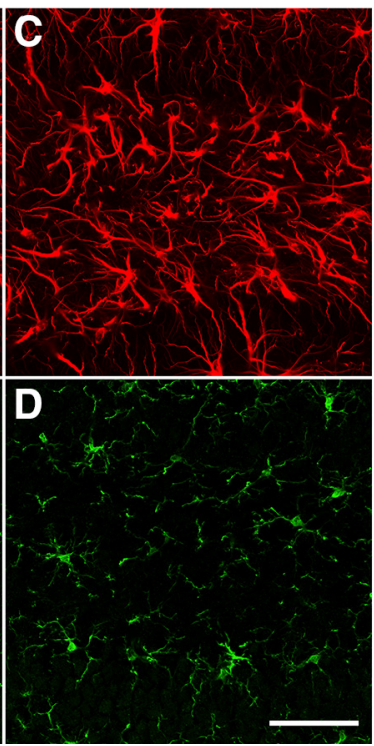
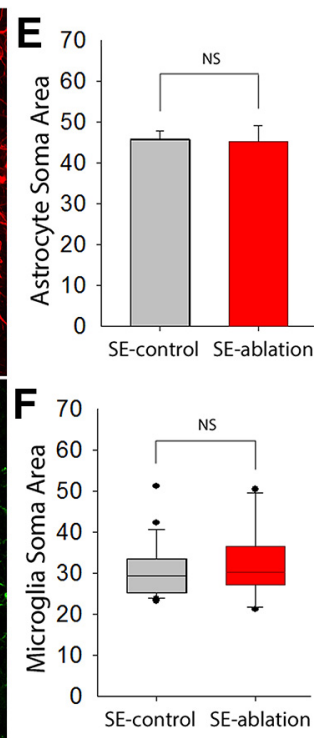

Figure 9. Ablation treatment does not affect astrogliosis or microgliosis. GFAP (red) and lba1 (green) expression in SE-control $(\boldsymbol{A}, \boldsymbol{B})$ and SE-ablation $(\boldsymbol{C}, \boldsymbol{D})$ mice. GFAP is expressed in astrocytes, whereas Iba1 is expressed in microglia. Graphs show the maximum profile area of astrocyte $(\boldsymbol{E})$ and microglia $(\boldsymbol{F})$ somas in SE-control (gray bars) and SE-ablation (red bars) mice (astrocyte: SE-control: $n=22$, SE-ablation: $n=10$, Student's $t$ test, $p=896$. Microglia: SE-control: $n=22$, SE-ablation: $n=10$, MannWhitney RST, $p=0.699)$. Data are represented as mean \pm SEM. Scale bar, $50 \mu \mathrm{m}$.

It is also possible that newly generated granule cells play dual roles, promoting seizure occurrence but limiting seizure duration. Mechanisms regulating seizure onset, spread, and termination are poorly understood, but there is no a priori reason to assume that a single cell population cannot regulate multiple aspects of seizure phenotype. Intriguingly, several studies now suggest that one function of newly generated granule cells in healthy animals is to enhance activation of inhibitory circuits. Lacefield et al. (2012) found that ablating granule cell progenitors increases gamma burst activity in the dentate and produces more coordinated firing of granule cells. Blocking adult neurogenesis also enhances excitation spread in the dentate gyrus in control animals (Ikrar et al., 2013). More recently, Drew et al. (2016) demonstrated that optogenetically exciting newly generated cells activated local inhibitory circuits, which in turn inhibited more mature granule cells. If newly generated granule cells in the epileptic brain retain robust connectivity with inhibitory networks, then ablating these cells might contribute to increased seizure duration.

\section{Heterogeneity among newly generated granule cells may limit treatment efficacy}

A limitation of the present study is that it was not possible to target distinct subpopulations of newly generated granule cells, which may make different, and perhaps opposing, contributions to epileptogenesis. Newly generated dentate granule cells consistently exhibit proexcitatory physiological and morphological changes in epilepsy models; however, these neurons can also exhibit changes suggestive of decreased excitatory input. Our own data demonstrate that $10 \%$ of newly generated granule cells show increased spine densities in the pilocarpine model, suggestive of increased excitability, whereas $90 \%$ exhibit reduced spine densities, suggestive of decreased excitability (Murphy et al., 2011). Physiological studies support these observations, with newly generated granule cells exhibiting both increased and decreased excitability in different epilepsy models (Jakubs et al., 2006; Wood et al., 2011; Gao et al., 2015). DT-mediated cell ablation, therefore, may remove both potentially hyperexcitable cells and cells that integrate to limit hippocampal excitability. The inability of the current ablation strategy to discriminate among granule cells might also underlie the increase in seizure duration if a subset of new cells acts to enhance seizure termination. Nevertheless, this study was designed to test the "net effect" of newly generated granule cells and the present findings suggest that this is proepileptogenic.

A second limitation of the study presented here is that ablation of newly generated granule cells is not complete. Crerecombinase technology cannot capture $100 \%$ of Nestin-expressing progenitor cells and immature neurons, including ectopically located granule cells, were still present in these animals. Nevertheless, it is notable that even this partial ablation was effective at reducing seizure frequency. Based on the present results, we predict that complete removal of ectopic cells would produce even greater reductions in seizure frequency.

Although the transgenic cell ablation strategy used here is not translatable to the clinical setting, the study provides essential proofof-principle data favoring the development of targeted cell ablation as a novel treatment for epilepsy. Even accounting for the increase in seizure duration, fewer long seizures is likely to be a desirable goal for patients with epilepsy because this is likely to be less disruptive of daily activities. Translational approaches might involve using existing U.S. Food and Drug Administration-approved antimitotic agents that can block neurogenesis or developing retroviral approaches that can target dividing neurons specifically (Zhao et al., 2006). Improved understanding of granule cell heterogeneity 
and function may allow for precise targeting of pathological populations in the future, with the potential for even more robust outcomes.

\section{References}

Acsády L, Kamondi A, Sík A, Freund T, Buzsáki G (1998) GABAergic cells are the major postsynaptic targets of mossy fibers in the rat hippocampus. J Neurosci 18:3386-3403. Medline

Ahn S, Joyner AL (2005) In vivo analysis of quiescent adult neural stem cells responding to Sonic hedgehog. Nature 437:894-897. CrossRef Medline

Aimone JB, Li Y, Lee SW, Clemenson GD, Deng W, Gage FH (2014) Regulation and function of adult neurogenesis: from genes to cognition. Physiol Rev 94:991-1026. CrossRef Medline

Althaus AL, Sagher O, Parent JM, Murphy GG (2015) Intrinsic neurophysiological properties of hilar ectopic and normotopic dentate granule cells in human temporal lobe epilepsy and a rat model. J Neurophysiol 113: 1184-1194. CrossRef Medline

Althaus AL, Zhang H, Parent JM (2016) Axonal plasticity of age-defined dentate granule cells in a rat model of mesial temporal lobe epilepsy. Neurobiol Dis 86:187-196. CrossRef Medline

Ang CW, Carlson GC, Coulter DA (2006) Massive and specific dysregulation of direct cortical input to the hippocampus in temporal lobe epilepsy. J Neurosci 26:11850-11856. CrossRef Medline

Behr J, Lyson KJ, Mody I (1998) Enhanced propagation of epileptiform activity through the kindled dentate gyrus. J Neurophysiol 79:1726-1732. Medline

Borges K, Gearing M, McDermott DL, Smith AB, Almonte AG, Wainer BH, Dingledine R (2003) Neuronal and glial pathological changes during epileptogenesis in the mouse pilocarpine model. Exp Neurol 182:21-34. CrossRef Medline

Brown JP, Couillard-Després S, Cooper-Kuhn CM, Winkler J, Aigner L, Kuhn HG (2003) Transient expression of doublecortin during adult neurogenesis. J Comp Neurol 467:1-10. CrossRef Medline

Buch T, Heppner FL, Tertilt C, Heinen TJ, Kremer M, Wunderlich FT, Jung S, Waisman A (2005) A Cre-inducible diphtheria toxin receptor mediates cell lineage ablation after toxin administration. Nat Methods 2:419-426. CrossRef Medline

Buckmaster PS (2014) Does mossy fiber sprouting give rise to the epileptic state? Adv Exp Med Biol 813:161-168. CrossRef Medline

Cameron MC, Zhan RZ, Nadler JV (2011) Morphologic integration of hilar ectopic granule cells into dentate gyrus circuitry in the pilocarpine model of temporal lobe epilepsy. J Comp Neurol 519:2175-2192. CrossRef Medline

Castro OW, Santos VR, Pun RY, McKlveen JM, Batie M, Holland KD, Gardner M, Garcia-Cairasco N, Herman JP, Danzer SC (2012) Impact of corticosterone treatment on spontaneous seizure frequency and epileptiform activity in mice with chronic epilepsy. PLoS One 7:e46044. CrossRef Medline

Cho KO, Lybrand ZR, Ito N, Brulet R, Tafacory F, Zhang L, Good L, Ure K, Kernie SG, Birnbaum SG, Scharfman HE, Eisch AJ, Hsieh J (2015) Aberrant hippocampal neurogenesis contributes to epilepsy and associated cognitive decline. Nat Commun 6:6606. CrossRef Medline

Cicero SA, Johnson D, Reyntjens S, Frase S, Connell S, Chow LM, Baker SJ, Sorrentino BP, Dyer MA (2009) Cells previously identified as retinal stem cells are pigmented ciliary epithelial cells. Proc Natl Acad Sci U S A 106:6685-6690. CrossRef Medline

Danzer SC (2012) Depression, stress, epilepsy and adult neurogenesis. Exp Neurol 233:22-32. CrossRef Medline

Danzer SC (2015) Adult neurogenesis: opening the gates of Troy from the inside. Epilepsy Curr 15:263-264. CrossRef Medline

Danzer SC, Kotloski RJ, Walter C, Hughes M, McNamara JO (2008) Altered morphology of hippocampal dentate granule cell presynaptic and postsynaptic terminals following conditional deletion of TrkB. Hippocampus 18:668-678. CrossRef Medline

Danzer SC, He X, Loepke AW, McNamara JO (2010) Structural plasticity of dentate granule cell mossy fibers during the development of limbic epilepsy. Hippocampus 20:113-124. CrossRef Medline

Drew LJ, Kheirbek MA, Luna VM, Denny CA, Cloidt MA, Wu MV, Jain S, Scharfman HE, Hen R (2016) Activation of local inhibitory circuits in the dentate gyrus by adult-born neurons. Hippocampus 26:763-778. CrossRef Medline

Eriksson PS, Perfilieva E, Björk-Eriksson T, Alborn AM, Nordborg C, Peter- son DA, Gage FH (1998) Neurogenesis in the adult human hippocampus. Nat Med 4:1313-1317. CrossRef Medline

Fujise N, Kosaka T (1999) Mossy cells in the mouse dentate gyrus: identification in the dorsal hilus and their distribution along the dorsoventral axis. Brain Res 816:500-511. CrossRef Medline

Fujita S, Toyoda I, Thamattoor AK, Buckmaster PS (2014) Preictal activity of subicular, CAl, and dentate gyrus principal neurons in the dorsal hippocampus before spontaneous seizures in a rat model of temporal lobe epilepsy. J Neurosci 34:16671-16687. CrossRef Medline

Gao F, Song X, Zhu D, Wang X, Hao A, Nadler JV, Zhan RZ (2015) Dendritic morphology, synaptic transmission, and activity of mature granule cells born following pilocarpine-induced status epilepticus in the rat. Front Cell Neurosci 9:384. CrossRef Medline

Garzillo CL, Mello LE (2002) Characterization of reactive astrocytes in the chronic phase of the pilocarpine model of epilepsy. Epilepsia 43:107-109. Medline

Gibbons MB, Smeal RM, Takahashi DK, Vargas JR, Wilcox KS (2013) Contributions of astrocytes to epileptogenesis following status epilepticus: opportunities for preventive therapy? Neurochem Int 63:660-669. CrossRef Medline

Heinemann U, Beck H, Dreier JP, Ficker E, Stabel J, Zhang CL (1992) The dentate gyrus as a regulated gate for the propagation of epileptiform activity. Epilepsy Res Suppl 7:273-280. Medline

Hester MS, Danzer SC (2013) Accumulation of abnormal adult-generated hippocampal granule cells predicts seizure frequency and severity. J Neurosci 33:8926-8936. CrossRef Medline

Hester MS, Hosford BE, Santos VR, Singh SP, Rolle IJ, LaSarge CL, Liska JP, Garcia-Cairasco N, Danzer SC (2016) Impact of rapamycin on status epilepticus induced hippocampal pathology and weight gain. Exp Neurol 280:1-12. CrossRef Medline

Hofacer RD, Deng M, Ward CG, Joseph B, Hughes EA, Jiang C, Danzer SC, Loepke AW (2013) Cell age-specific vulnerability of neurons to anesthetic toxicity. Ann Neurol 73:695-704. CrossRef Medline

Howell K, Hopkins N, McLoughlin P (2002) Combined confocal microscopy and stereology: a highly efficient and unbiased approach to quantitative structural measurement in tissues. Exp Physiol 87:747-756. CrossRef Medline

Hsu D (2007) The dentate gyrus as a filter or gate: a look back and a look ahead. Prog Brain Res 163:601-613. CrossRef Medline

Ikrar T, Guo N, He K, Besnard A, Levinson S, Hill A, Lee HK, Hen R, Xu X, Sahay A (2013) Adult neurogenesis modifies excitability of the dentate gyrus. Front Neural Circuits 7:204. CrossRef Medline

Iyengar SS, LaFrancois JJ, Friedman D, Drew LJ, Denny CA, Burghardt NS, Wu MV, Hsieh J, Hen R, Scharfman HE (2015) Suppression of adult neurogenesis increases the acute effects of kainic acid. Exp Neurol 264: 135-149. CrossRef Medline

Jakubs K, Nanobashvili A, Bonde S, Ekdahl CT, Kokaia Z, Kokaia M, Lindvall O (2006) Environment matters: synaptic properties of neurons born in the epileptic adult brain develop to reduce excitability. Neuron 52:10471059. CrossRef Medline

Jessberger S, Parent JM (2015) Epilepsy and adult neurogenesis. Cold Spring Harb Perspect Biol 7: pii: a020677. CrossRef Medline

Jessberger S, Zhao C, Toni N, Clemenson GD Jr, Li Y, Gage FH (2007) Seizure-associated, aberrant neurogenesis in adult rats characterized with retrovirus-mediated cell labeling. J Neurosci 27:9400-9407. CrossRef Medline

Jiao Y, Nadler JV (2007) Stereological analysis of GluR2-immunoreactive hilar neurons in the pilocarpine model of temporal lobe epilepsy: correlation of cell loss with mossy fiber sprouting. Exp Neurol 205:569-582. CrossRef Medline

Jinde S, Zsiros V, Jiang Z, Nakao K, Pickel J, Kohno K, Belforte JE, Nakazawa K (2012) Hilar mossy cell degeneration causes transient dentate granule cell hyperexcitability and impaired pattern separation. Neuron 76:1189 1200. CrossRef Medline

Jung KH, Chu K, Kim M, Jeong SW, Song YM, Lee ST, Kim JY, Lee SK, Roh JK (2004) Continuous cytosine-b-D-arabinofuranoside infusion reduces ectopic granule cells in adult rat hippocampus with attenuation of spontaneous recurrent seizures following pilocarpine-induced status epilepticus. Eur J Neurosci 19:3219-3226. CrossRef Medline

Jung KH, Chu K, Lee ST, Kim J, Sinn DI, Kim JM, Park DK, Lee JJ, Kim SU, Kim M, Lee SK, Roh JK (2006) Cyclooxygenase-2 inhibitor, celecoxib, inhibits the altered hippocampal neurogenesis with attenuation of spon- 
taneous recurrent seizures following pilocarpine-induced status epilepticus. Neurobiol Dis 23:237-246. CrossRef Medline

Kang W, Balordi F, Su N, Chen L, Fishell G, Hébert JM (2014) Astrocyte activation is suppressed in both normal and injured brain by FGF signaling. Proc Natl Acad Sci U S A 111:E2987-E2995. CrossRef Medline

Kron MM, Zhang H, Parent JM (2010) The developmental stage of dentate granule cells dictates their contribution to seizure-induced plasticity. J Neurosci 30:2051-2059. CrossRef Medline

Krook-Magnuson E, Armstrong C, Bui A, Lew S, Oijala M, Soltesz I (2015) In vivo evaluation of the dentate gate theory in epilepsy. J Physiol 593: 2379-2388. CrossRef Medline

Kurz JE, Moore BJ, Henderson SC, Campbell JN, Churn SB (2008) A cellular mechanism for dendritic spine loss in the pilocarpine model of status epilepticus. Epilepsia 49:1696-1710. CrossRef Medline

Lacefield CO, Itskov V, Reardon T, Hen R, Gordon JA (2012) Effects of adult-generated granule cells on coordinated network activity in the dentate gyrus. Hippocampus 22:106-116. CrossRef Medline

Lee KM, MacLean AG (2015) New advances on glial activation in health and disease. World J Virol 4:42-55. CrossRef Medline

McAuliffe JJ, Bronson SL, Hester MS, Murphy BL, Dahlquist-Topalá R, Richards DA, Danzer SC (2011) Altered patterning of dentate granule cell mossy fiber inputs onto CA3 pyramidal cells in limbic epilepsy. Hippocampus 21:93-107. CrossRef Medline

Mizumatsu S, Monje ML, Morhardt DR, Rola R, Palmer TD, Fike JR (2003) Extreme sensitivity of adult neurogenesis to low doses of X-irradiation. Cancer Res 63:4021-4027. Medline

Monje ML, Mizumatsu S, Fike JR, Palmer TD (2002) Irradiation induces neural precursor-cell dysfunction. Nat Med 8:955-962. CrossRef Medline

Müller M, Gähwiler BH, Rietschin L, Thompson SM (1993) Reversible loss of dendritic spines and altered excitability after chronic epilepsy in hippocampal slice cultures. Proc Natl Acad Sci U S A 90:257-261. CrossRef Medline

Murphy BL, Pun RY, Yin H, Faulkner CR, Loepke AW, Danzer SC (2011) Heterogeneous integration of adult-generated granule cells into the epileptic brain. J Neurosci 31:105-117. CrossRef Medline

Murphy BL, Hofacer RD, Faulkner CN, Loepke AW, Danzer SC (2012) Abnormalities of granule cell dendritic structure are a prominent feature of the intrahippocampal kainic acid model of epilepsy despite reduced postinjury neurogenesis. Epilepsia 53:908-921. CrossRef Medline

Myers CE, Bermudez-Hernandez K, Scharfman HE (2013) The influence of ectopic migration of granule cells into the hilus on dentate gyrus-CA3 function. PLoS One 8:e68208. CrossRef Medline

Nakamura T, Colbert MC, Robbins J (2006) Neural crest cells retain multipotential characteristics in the developing valves and label the cardiac conduction system. Circ Res 98:1547-1554. CrossRef Medline

Pai VP, Lemire JM, Paré JF, Lin G, Chen Y, Levin M (2015) Endogenous gradients of resting potential instructively pattern embryonic neural tissue via Notch signaling and regulation of proliferation. J Neurosci 35: 4366-4385. CrossRef Medline

Pun RY, Rolle IJ, Lasarge CL, Hosford BE, Rosen JM, Uhl JD, Schmeltzer SN, Faulkner C, Bronson SL, Murphy BL, Richards DA, Holland KD, Danzer SC (2012) Excessive activation of mTOR in postnatally generated granule cells is sufficient to cause epilepsy. Neuron 75:1022-1034. CrossRef Medline

Racine RJ (1972) Modification of seizure activity by electrical stimulation. II. Motor seizure. Electroencephalogr Clin Neurophysiol 32:281-294. CrossRef Medline

Ratzliff Ad, Howard AL, Santhakumar V, Osapay I, Soltesz I (2004) Rapid deletion of mossy cells does not result in a hyperexcitable dentate gyrus: implications for epileptogenesis. J Neurosci 24:2259-2269. CrossRef Medline

Rola R, Raber J, Rizk A, Otsuka S, VandenBerg SR, Morhardt DR, Fike JR (2004) Radiation-induced impairment of hippocampal neurogenesis is associated with cognitive deficits in young mice. Exp Neurol 188:316330. CrossRef Medline

Saijo K, Glass CK (2011) Microglial cell origin and phenotypes in health and disease. Nat Rev Immunol 11:775-787. CrossRef Medline
Scharfman HE, Myers CE (2012) Hilar mossy cells of the dentate gyrus: a historical perspective. Front Neural Circuits 6:106. CrossRef Medline

Scharfman HE, Myers CE (2016) Corruption of the dentate gyrus by "dominant" granule cells: Implications for dentate gyrus function in health and disease. Neurobiol Learn Mem 129:69-82. CrossRef Medline

Scharfman HE, Goodman JH, Sollas AL (2000) Granule-like neurons at the hilar/CA3 border after status epilepticus and their synchrony with area CA3 pyramidal cells: functional implications of seizure-induced neurogenesis. J Neurosci 20:6144-6158. Medline

Scharfman HE, Sollas AE, Berger RE, Goodman JH, Pierce JP (2003) Perforant path activation of ectopic granule cells that are born after pilocarpineinduced seizures. Neuroscience 121:1017-1029. CrossRef Medline

Schmidt-Hieber C, Jonas P, Bischofberger J (2004) Enhanced synaptic plasticity in newly generated granule cells of the adult hippocampus. Nature 429:184-187. CrossRef Medline

Singer BH, Gamelli AE, Fuller CL, Temme SJ, Parent JM, Murphy GG (2011) Compensatory network changes in the dentate gyrus restore long-term potentiation following ablation of neurogenesis in young-adult mice. Proc Natl Acad Sci U S A 108:5437-5442. CrossRef Medline

Singh SP, He X, McNamara JO, Danzer SC (2013) Morphological changes among hippocampal dentate granule cells exposed to early kindlingepileptogenesis. Hippocampus 23:1309-1320. CrossRef Medline

Singh SP, LaSarge CL, An A, McAuliffe JJ, Danzer SC (2015) Clonal analysis of newborn hippocampal dentate granule cell proliferation and development in temporal lobe epilepsy. eNeuro 2: pii: ENEURO.0087-15.2015. CrossRef Medline

Smith BL, Schmeltzer SN, Packard BA, Sah R, Herman JP (2016) Divergent effects of repeated restraint versus chronic variable stress on prefrontal cortical immune status after LPS injection. Brain Behav Immun 57:263270. CrossRef Medline

Spalding KL, Bergmann O, Alkass K, Bernard S, Salehpour M, Huttner HB, Boström E, Westerlund I, Vial C, Buchholz BA, Possnert G, Mash DC, Druid H, Frisén J (2013) Dynamics of hippocampal neurogenesis in adult humans. Cell 153:1219-1227. CrossRef Medline

Sun MY, Yetman MJ, Lee TC, Chen Y, Jankowsky JL (2014) Specificity and efficiency of reporter expression in adult neural progenitors vary substantially among nestin-CreER(T2) lines. J Comp Neurol 522:1191-1208. CrossRef Medline

Swann JW, Al-Noori S, Jiang M, Lee CL (2000) Spine loss and other dendritic abnormalities in epilepsy. Hippocampus 10:617-625. Medline

Tejada J, Garcia-Cairasco N, Roque AC (2014) Combined role of seizureinduced dendritic morphology alterations and spine loss in newborn granule cells with mossy fiber sprouting on the hyperexcitability of a computer model of the dentate gyrus. PLoS Comput Biol 10:e1003601. CrossRef Medline

Vezzani A, Lang B, Aronica E (2016) Immunity and inflammation in epilepsy. Cold Spring Harb Perspect Med 6:a022699. CrossRef Medline

Vukovic J, Borlikova GG, Ruitenberg MJ, Robinson GJ, Sullivan RK, Walker TL, Bartlett PF (2013) Immature doublecortin-positive hippocampal neurons are important for learning but not for remembering. J Neurosci 33:6603-6613. CrossRef Medline

Walter C, Murphy BL, Pun RY, Spieles-Engemann AL, Danzer SC (2007) Pilocarpine-induced seizures cause selective time-dependent changes to adult-generated hippocampal dentate granule cells. J Neurosci 27:75417552. CrossRef Medline

Wood JC, Jackson JS, Jakubs K, Chapman KZ, Ekdahl CT, Kokaia Z, Kokaia M, Lindvall O (2011) Functional integration of new hippocampal neurons following insults to the adult brain is determined by characteristics of pathological environment. Exp Neurol 229:484-493. CrossRef Medline

Zhan RZ, Timofeeva O, Nadler JV (2010) High ratio of synaptic excitation to synaptic inhibition in hilar ectopic granule cells of pilocarpine-treated rats. J Neurophysiol 104:3293-3304. CrossRef Medline

Zhao C, Teng EM, Summers RG Jr, Ming GL, Gage FH (2006) Distinct morphological stages of dentate granule neuron maturation in the adult mouse hippocampus. J Neurosci 26:3-11. CrossRef Medline 